Special Issue of the 6th International Congress \& Exhibition (APMAS2016), Maslak, Istanbul, Turkey, June 1-3, 2016

\title{
Preparation and Phase Transformation of Mullite-Zirconia from Boehmite and Algerian Halloysite
}

\begin{abstract}
A. Raghdi*, M. Heraiz, F. Sahnoune, A. Ouali and D. Redaoui
Physics and Chemistry of Materials Lab, Department of Physics, University Mohamed Boudiaf of M'sila, 28000, M'sila, Algeria

In this work, mullite-zirconia composite were fabricated by reaction sintering of Algerian halloysite $\mathrm{Al}_{2} \mathrm{Si}_{2} \mathrm{O}_{5}(\mathrm{OH})_{4}$, boehmite $\mathrm{Al}(\mathrm{OOH})$, and zirconia $\left(\mathrm{ZrO}_{2}\right)$ powder using conventional heating. The appropriate amount of the three raw powders was ball milled for $5 \mathrm{~h}$ and sintered between 1250 and $1650^{\circ} \mathrm{C}$ for $2 \mathrm{~h}$. A scanning electron microscope was used to characterize the microstructure of sintered samples. A dilatometer and X-ray diffractometer were used to analyze the formation and transformation of phases. It is found that for the addition of zirconia up to $20 \mathrm{wt} . \%$ the zirconia phase retains its tetragonal structure. The formation of primary mullite in all samples was complete at $1220^{\circ} \mathrm{C}$. The cristobalite started to form at $1350^{\circ} \mathrm{C}$, and disappeared at $1500^{\circ} \mathrm{C}$ in the samples of mullite, and at $1450^{\circ} \mathrm{C}$ when $\mathrm{ZrO}_{2}$ was added. The zircon compound $\mathrm{ZrSiO}_{4}$ started to form at $1350^{\circ} \mathrm{C}$ and completely disappeared at $1550^{\circ} \mathrm{C}$. The increase in $\mathrm{ZrO}_{2}$ ratio promoted the formation of grains with a spherical shape.
\end{abstract}

DOI: $10.12693 /$ APhysPolA.131.136

PACS/topics: 81.05.Mh, 68.37.hk, 07.85.Nc

\section{Introduction}

Mullite is one of the basal ceramic materials traditionally used for refractories and is attractive because of its high melting point, thermal expansion coefficient and low thermal conductivity $[1,2]$, and excellent electrical insulating capability [3]. However, mullite ceramics exhibit both low strength and fracture toughness at room temperature. It is, therefore, necessary to use reinforced mullite ceramics with particles or fibers to produce composites with superior properties [1]. Many methods have been used to prepare mullite such as sintering, sol-gel [4], and coprecipitation. However, the high cost associated with these methods made it unattractive for commercial app lications. Synthesis of mullite from clay [5] remains an economical way to prepare mullite with desired properties [6]. It is also well known that the reactivity of halloysite clay changes as it undergoes these thermal transitions. The rate of mullite formation depends on the temperature of the reaction. Mullite- $\mathrm{ZrO}_{2}$ composites have been prepared through many processes [7] including sintering of mixed mullite and $\mathrm{ZrO}_{2}$ powders, reaction sintering of zircon and alumina is a well-established method for producing mullite-zirconia ceramics. The zircon dissociates at high temperature and the $\mathrm{ZrO}_{2}$ and $3 \mathrm{Al}_{2} \mathrm{O}_{3} \cdot 2 \mathrm{SiO}_{2}$ form.

The addition of $\mathrm{ZrO}_{2}$ promotes densification and retards grain growth of mullite phase in mullite-zirconia composites [8]. In this work, we synthesized mullitezirconia composite through reaction sintering of Algerian halloysite, boehmite, and $\mathrm{ZrO}_{2}$ and investigated the phase transformation of the composite.

\footnotetext{
* corresponding author; e-mail: raghdiamina@yahoo.fr
}

\section{Material and experimental procedure}

Algerian raw halloysite (from Djabal Debagh), boehmite, and zirconia were used in this investigation. The powder mixtures were prepared to obtain $80 / 20$ mullite $/ \mathrm{ZrO}_{2}$ composites, and this is named HB20Z. In order to prepare a homogeneous mixture of halloysite, boehmite and zirconia, the ball milling technique was used [9]. This technique was used to develop many advanced materials including compounds as oxide-dispersion-strengthened compounds of composites and nanocomposites. The mixture of the raw powders was charged into cylindrical zirconia vials together with 15 zirconia balls. The water was added to the mixture at a ratio of 2:1. The experiments were performed in a high-energy planetary ball mill (Fritsch P6) and were carried out at room temperature with a rotation speed of $250 \mathrm{rpm}$. Finally, the milled mixture was dried at $150^{\circ} \mathrm{C}$ for $24 \mathrm{~h}$, then compacted at $75 \mathrm{MPa}$ by using the uniaxial press. The present phases and their transformations were characterized by a high resolution diffractometer MRD, PANalytical (ISM), of a wavelength equal to $1.5418 \AA$. The scanning electron microscope (SEM) was used to characterize the microstructure of sintered samples. Dilatometry experiments performed on samples were heated from room temperature up to $1600^{\circ} \mathrm{C}$, at heating rates of $5^{\circ} \mathrm{C} / \mathrm{min}$ by using NETZSCH (Dil 402C) equipment.

\section{Results and discussion}

Figure 1 shows linear shrinkage of halloysiteboehmite-zirconia (sample HB20Z) mixture heated at a rate of $0.5{ }^{\circ} \mathrm{C} / \mathrm{min}$. This shrinkage curve shows reactions that could take place during heating and are discussed below. Relative expansion at a temperature inferior that $150{ }^{\circ} \mathrm{C}$ is due to the evaporation of adsorbed water, and the rate of evaporation is maximal at around 
$90^{\circ} \mathrm{C}$. A relative shrinkage starts at $467^{\circ} \mathrm{C}$ and ends at $636^{\circ} \mathrm{C}$, where the rate of shrinkage is maximal at $567^{\circ} \mathrm{C}$. This shrinkage is due to the dehydration of the halloysite which transforms to metahalloysite. A third relative shrinkage is a result of the transformation of metahalloysite to spinel ( $\mathrm{Al}-\mathrm{Si})$, where the rate of shrinkage is maximal at $980^{\circ} \mathrm{C}[10]$, and also the transformation of spinel phase $(\mathrm{Al}-\mathrm{Si})$ to silica in the form of cristobalite and primary mullite at $1239^{\circ} \mathrm{C}$ and this reaction ends at a temperature lower than $1400^{\circ} \mathrm{C}$. A relative shrinkage starts at $1354^{\circ} \mathrm{C}$ and ends at $1460{ }^{\circ} \mathrm{C}$, where the rate of shrinkage is maximal at $1412{ }^{\circ} \mathrm{C}$. The shrinkage is due to the formation of $\mathrm{ZrSiO}_{4}$ from $\mathrm{ZrO}_{2}$ and $\mathrm{SiO}_{2}$ [11]. Finally, the secondary mullite (which results from the reaction of the added $\mathrm{Al}_{2} \mathrm{O}_{3}$ with $\mathrm{SiO}_{2}$ remaining from the formation of primary mullite) formed at a temperature above $1501^{\circ} \mathrm{C}$.

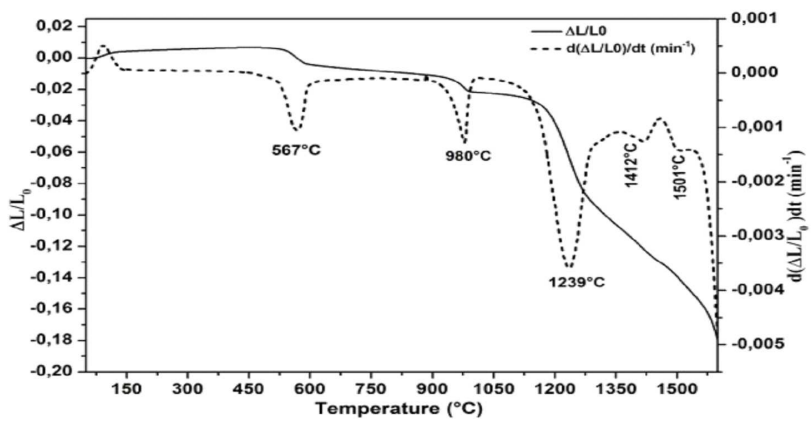

Fig. 1. Dilatometry studies on unfired halloysiteboehmite-zirconia samples.

Figure 2 shows XRD spectra of two samples (HB00Z and HB20Z) sintered at various temperatures between 1250 and $1650^{\circ} \mathrm{C}$ for $2 \mathrm{~h}$. It is clear that mullite started to form below $1250{ }^{\circ} \mathrm{C}$ (primary mullite that forms from spinel). On the other hand, the cristobalite begins to form from amorphous $\mathrm{SiO}_{2}$ near $1300^{\circ} \mathrm{C}$ and vanishes at $1500^{\circ} \mathrm{C}$ in the sample of HB00Z. While for the HB20Z samples, the cristobalite disappeared at $1500^{\circ} \mathrm{C}$. Zircon $\left(\mathrm{ZrSiO}_{4}\right)$ starts to appear at $1350^{\circ} \mathrm{C}$ (sample $\mathrm{HB} 20 \mathrm{Z}$ ) and dissolves to give $\mathrm{ZrO}_{2}$ and $\mathrm{SiO}_{2}$ after $1550^{\circ} \mathrm{C}$ [12]. It has been reported that zircon forms from the reaction of zirconia with silica at 1300 and $1400^{\circ} \mathrm{C}$ [11]. Also, it is known that pure zircon usually dissociates at higher temperature (over $1675^{\circ} \mathrm{C}$ ), whereas in the presence of impurities, zircon dissociates at temperature below $1675^{\circ} \mathrm{C}$ [13]. Monoclinic $\mathrm{ZrO}_{2}$ starts below $1250^{\circ} \mathrm{C}$, and $\mathrm{ZrO}_{2}$ stabilization in the amorphous matrix is lost, giving rise to $\mathrm{m}-\mathrm{ZrO}_{2}$ formation with increase of sintering temperature.

Figure 3 shows the scanning electron microstructure of polished and thermally etched surface of two samples sintered at $1600^{\circ} \mathrm{C}$ for $2 \mathrm{~h}$. As expected with the X-ray analysis, the microstructure of two samples shows a mullitezirconia composite for sample HB20Z and only mullite for sample HB00Z. We note a homogeneous microstructure with a uniformly distributed porosity. All samples

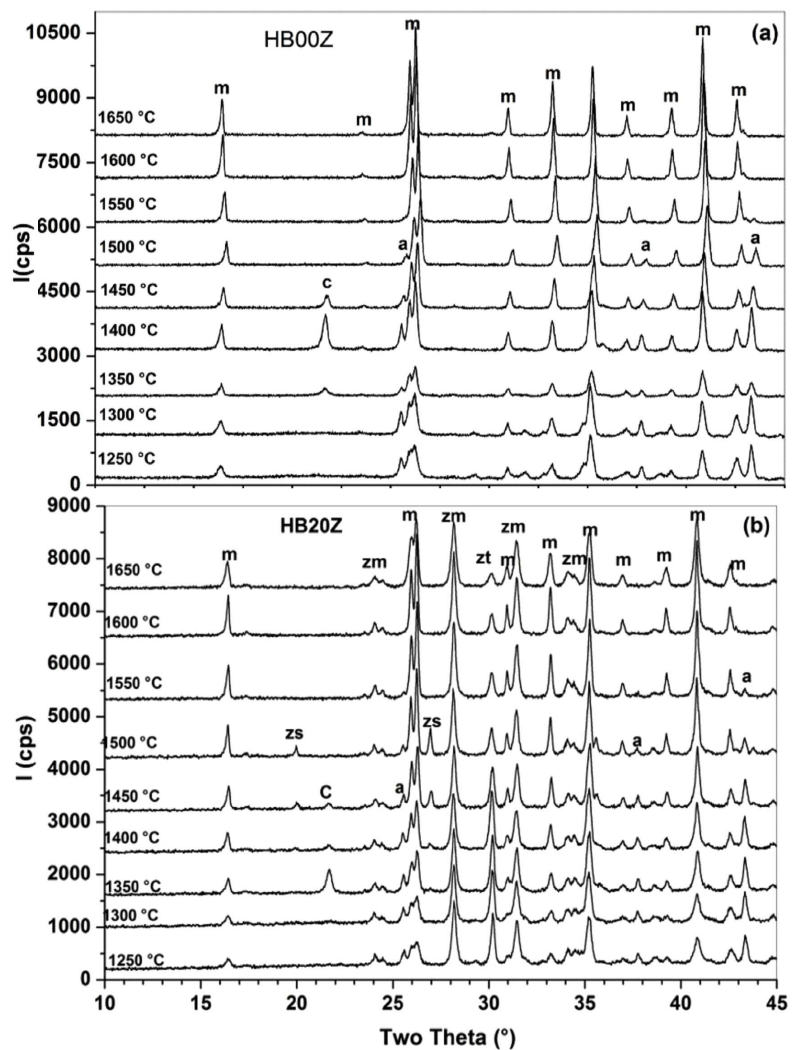

Fig. 2. XRD patterns of (a) HB00Z and (b) HB20Z samples treated at shown temperatures for $2 \mathrm{~h}$ : $\mathrm{m}$ mullite; zs - zircon; zm - monoclinic zirconia; zt tetragonal zirconia; a - $\alpha$-alumina; $\mathrm{c}-$ cristobalite.

are composed of irregularly large shaped mullite grains (Fig. 3a), and round shaped zirconia grains (Fig. 3b) which are distributed both intergranularly and intragranularly. Intergranular zirconia is localized especially in a triple point of the mullite/mullite particles or at the vicinity of the pores. The $\mathrm{ZrO}_{2}$ formed intergranular, isolated particles.

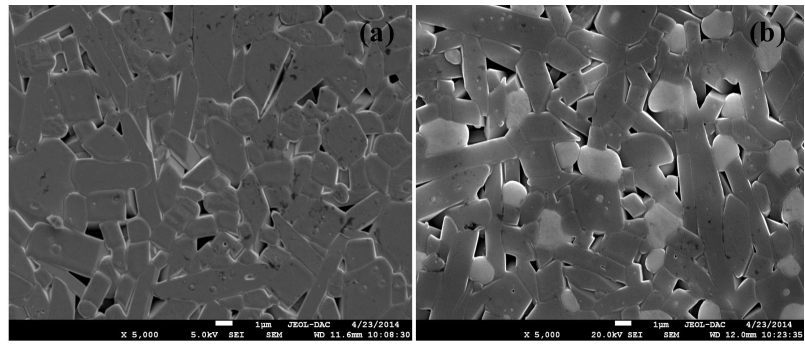

Fig. 3. Micrographs (SEM) of fractured surface of sample sintered at 1600 for $2 \mathrm{~h}$ : (a) HBOOZ and (b) HB20Z.

\section{Conclusion}

Algerian halloysite and boehmite were suitable raw materials for the synthesis of mullite- $\mathrm{ZrO}_{2}$ composites through reaction sintering. Phase transformation and 
sintering behavior of the developed composites were investigated. It was found that mullite was the dominant phase present in the sintered samples and also concluded that the zirconia phase retained its tetragonal and monoclinic structure. The formation of primary mullite in all samples was complete at $1350^{\circ} \mathrm{C}$. The cristobalite started to form at $1300^{\circ} \mathrm{C}$, and disappeared at $1500^{\circ} \mathrm{C}$ in the samples of mullite, and at $1450^{\circ} \mathrm{C}$ when $\mathrm{ZrO}_{2}$ was added. The zircon compound $\mathrm{ZrSiO}_{4}$ began to form at $1350^{\circ} \mathrm{C}$ and completely disappeared at $1550{ }^{\circ} \mathrm{C}$ in the sample of $\mathrm{HB} 20 \mathrm{Z}$. Also, the addition of $\mathrm{ZrO}_{2}$ promoted densification and retarded grain growth of the mullite phase.

\section{References}

[1] B. Kong, T.S. Zhang, Y.Z. Chen, J. Ma, F. Boey, H. Huang, Ceram. Int. 30, 1313 (2004).

[2] M.M.S. Wahsh, R.M. Khattab, M. Awaad, Mater. Des. 41, 31 (2012).

[3] V. Viswabaskaran, F.D. Gnanam, M. Balasubramanian, Appl. Clay Sci. 25, 29 (2004).
[4] D. Amutharani, F.D. Gnanam, Mater. Sci. Eng. A 264, 254 (1999).

[5] V. Viswabaskaran, F.D. Gnanam, M. Balasubramanian, J. Mater. Process. Technol. 142, 275 (2003).

[6] M.A. Sainz, F.J. Serrano, J. Bastida, A. Caballero, J. Eur. Ceram. Soc. 17, 1277 (1997).

[7] F. Sahnoune, H. Belhouchet, N. Saheb, M. Heraiz, M. Chegaar, P. Goeuriot, Adv. Appl. Ceram. 110, 175 (2011).

[8] S. Prochazka, J.S. Wallace, N. Claussen, J. Am. Ceram. Soc. 66, C-125 (1983).

[9] A.M. Al-Qutub, A. Khalil, N. Saheb, N. Al-Aqeeli, T. Laoui, Sci. Adv. Mater. 4, 1166 (2012).

[10] J.A. Pask, A.P. Tomsia, J. Am. Ceram. Soc. 74, 2367 (1991).

[11] S.V. Ramani, E.C. Subbarao, K.V.G.K. Gokhale, J. Am. Ceram. Soc. 52, 619 (1969).

[12] R.G. Carrodeguas, S. De Aza, Acta Biomater. 7, 3536 (2011).

[13] Y. Shi, X. Huang, D. Yan, Ceram. Int. 23, 457 (1997). 